\title{
The influence of episodic flooding on a pelagic ecosystem in the East China Sea
}

\author{
Chung-Chi Chen ${ }^{1}$, Gwo-Ching Gong ${ }^{2}$, Wen-Chen Chou ${ }^{2}$, Chih-Ching Chung ${ }^{2}$, Chih-Hao Hsieh ${ }^{3}$, Fuh-Kwo Shiah ${ }^{2,4}$, \\ and Kuo-Ping Chiang ${ }^{2}$ \\ ${ }^{1}$ Department of Life Science, National Taiwan Normal University, Taipei 116, Taiwan \\ ${ }^{2}$ Institute of Marine Environment and Ecology, National Taiwan Ocean University, Keelung 20224, Taiwan \\ ${ }^{3}$ Institute of Oceanography, National Taiwan University, Taipei 10617, Taiwan \\ ${ }^{4}$ Research Center for Environmental Changes, Academia Sinica, Nankang Taipei 115, Taiwan
}

Correspondence to: Chung-Chi Chen (ccchen@ntnu.edu.tw)

Received: 6 June 2016 - Discussion started: 27 June 2016

Revised: 11 April 2017 - Accepted: 27 April 2017 - Published: 22 May 2017

\begin{abstract}
This study was designed to determine the effects of flooding on a pelagic ecosystem in the East China Sea (ECS) with a focus on plankton activity and plankton community respiration (CR). In July 2010, a flood occurred in the Changjiang River. As a comparison, a variety of abiotic and biotic parameters were monitored during this flooding event and during a non-flooding period (July 2009). During the flood, the Changjiang diluted water (CDW) zone covered almost two-thirds of the ECS, which was approximately 6 times the area covered during the non-flooding period. The mean nitrate concentration was 3-fold higher during the 2010 flood (6.2 vs. $2.0 \mu \mathrm{M}$ in 2009). CR was also higher in the 2010 flood: $105.6 \mathrm{mg} \mathrm{C} \mathrm{m}^{-3} \mathrm{~d}^{-1}$ vs. only $73.2 \mathrm{mg} \mathrm{C} \mathrm{m}^{-3} \mathrm{~d}^{-1}$ in 2009. The higher CR in 2010 could be attributed to phytoplankton respiration, especially at stations in the CDW zone that were not previously characterized by low sea surface salinity in 2009. In addition, zooplankton $(>330 \mu \mathrm{m})$ were another important component contributing to the high CR rate observed during the 2010 flood; this was a period also associated with a significant degree of $f \mathrm{CO}_{2}$ drawdown. These results collectively suggest that the 2010 flood had a significant effect on the carbon balance in the ECS. This effect might become more pronounced in the future, as extreme rainfall and flooding events are predicted to increase in both frequency and magnitude due to climate change.
\end{abstract}

\section{Introduction}

Riverine runoff has a profound effect on the production and consumption of organic carbon in coastal ecosystems (e.g., Dagg et al., 2004; Hedges et al., 1997 and the references therein). Accompanying freshwater discharge, a substantial amount of dissolved inorganic nutrients (DINs) is routinely dispensed into coastal regions, thus enhancing primary productivity (PP; e.g., Dagg et al., 2004; Nixon et al., 1996). In addition, a large quantity of particulate and dissolved organic matter is discharged via riverine input (e.g., Wang et al., 2012), and high rates of microbial metabolism associated with this discharge have been observed in marine environments (e.g., Hedges et al., 1994; Malone and Ducklow, 1990). River plumes can extend for hundreds of kilometers along the continental shelf, as in the case of the Amazon River (e.g., Müller-Karger et al., 1988).

Overall, the effects of river plumes on coastal ecosystems are strongly related to the volume of the freshwater discharged (e.g., Chen et al., 2009; Dagg et al., 2004; Tian et al., 1993). Thus, understanding how freshwater discharge influences coastal ecological processes is an important factor in modeling global carbon cycling in the ocean. Under projected climate change scenarios, such heavy freshwater discharge events are predicted to become even more pronounced in the near future because of the dramatic frequency and magnitude increases in extreme rainfall events and floods predicted to occur throughout the world in the coming decades (Christensen and Christensen, 2003; Knox, 1993; Milly et al., 2002; Palmer and Ralsanen, 2002). 



Figure 1. Contour plots of salinity (SSS) and concentrations of nitrate $\left(\mathrm{NO}_{3}^{-}\right)$, phosphate $\left(\mathrm{PO}_{4}^{3-}\right)$, and chlorophyll $a(\mathrm{Chl} a)$ in the surface water (2-3 m) in the ECS during non-flooding (2009; left panels) and flooding (2010; right panels) periods. Bottom depth contours are shown as dashed lines both here and in Fig. 2. The sampling stations in both periods are marked by an (x) both here and in Fig. 2. The contour intervals of SSS and concentrations of nitrate, phosphate, and Chl $a$ are $0.5,1.0 \mu \mathrm{M}, 0.1 \mu \mathrm{M}$, and $0.5 \mathrm{mg} \mathrm{Chl} \mathrm{m}^{-3}$, respectively, and the values of the respective contour lines (bold) are $31,3.0 \mu \mathrm{M}, 1.0 \mu \mathrm{M}$, and $1.0 \mathrm{mg} \mathrm{Chl} \mathrm{m}^{-3}$, respectively. The range for each parameter is shown at the top of each panel. 
The East China Sea (ECS) has an approximate area of $0.5 \times 10^{6} \mathrm{~km}^{2}$ and is the largest marginal sea in the Western Pacific. A large amount of freshwater $\left(956 \mathrm{~km}^{3} \mathrm{yr}^{-1}\right)$ is discharged annually into the ECS, notably by the Changiiang (also called the Yangtze) River, which is the fifth largest river in the world in terms of volume discharge (Liu et al., 2010). On average, the maximum amount of discharge occurs in July, and the mean monthly discharge has ranged from 33955 to $40943 \mathrm{~m}^{3} \mathrm{~s}^{-1}$ in years of normal weather during the past decade (Gong et al., 2011; Xu and Milliman, 2009). After being discharged into the ECS, freshwater mixes with seawater to form the Changjiang diluted water (CDW) zone. The sea surface salinity (SSS) of the CDW is $\leq 31$ (e.g., Beardsley et al., 1985; Gong et al., 1996). In the CDW, especially in summer, the regional carbon balance is regulated by high rates of plankton community respiration (CR) and PP (Chen et al., 2006; Gong et al., 2003). The CR rates are positively associated with riverine flow rates (Chen et al., 2009).

In July 2010, a large flood occurred in the Changjiang River (Gong et al., 2011). This event provided an opportunity to understand how flooding affects the ECS shelf ecosystem. Comparative analyses were conducted in which a number of physical, chemical, and biological parameters (notably CR) were measured not only during this flood, but also during a period (July 2009) when the riverine flow was relatively low. The main objective of this study was to reveal the effects of riverine input, particularly the associated DINs, on plankton activities (e.g., phytoplankton, heterotrophic bacteria, and zooplankton; $>330 \mu \mathrm{m}$ ) and how they impact the CR in the ECS between periods of non-flooding and flooding. In addition, the relationship between $\mathrm{CR}$ and the fugacity of $\mathrm{CO}_{2}\left(f \mathrm{CO}_{2}\right)$ was examined to determine the contribution of the plankton communities to variations in $f \mathrm{CO}_{2}$ in periods of non-flooding and flooding.

\section{Materials and methods}

\subsection{Study area and sampling protocol}

This study is part of the Long-term Observation and Research of the East China Sea (LORECS) program. Samples were collected from the ECS in the summers of 2009 (29 June to 13 July) and 2010 (6 to 18 July) during two cruises on the R/V Ocean Researcher I. The sample stations were located throughout the ECS shelf region (Fig. 1). In July 2010, the discharge from the Changjiang River reached $60527 \mathrm{~m}^{3} \mathrm{~s}^{-1}$, which was significantly higher than in the non-flooding year of 2009 (Gong et al., 2011; Yu et al., 2009). Water samples were collected using Teflon-coated Go-Flo bottles $(20 \mathrm{~L}$; General Oceanics Inc., Miami, FL, USA) mounted on a General Oceanics Rosette ${ }^{\circledR}$ assembly (model 1015; General Oceanics Inc.). At each station, six to nine samples were taken at depths of 3 to $50 \mathrm{~m}$, depending on the depth of the water column. Subsamples were taken for immediate analy- sis of DINs, chlorophyll $a(\mathrm{Chl} a)$, and bacterial abundance. Plankton CR was also measured onboard from seawater subsamples. The methods used to collect the hydrographic data and analyze the aforementioned response variables followed Chen et al. (2006, 2013, 2009). Descriptions of the methods used are presented briefly in the following sections. It should also be noted that portions of these results were published by Chung et al. (2014) and Gong et al. (2011).

\subsection{Physical and chemical hydrographics}

Seawater temperature, salinity, and transparency were recorded throughout the water column using a Sea-Bird CTD (Sea-Bird Scientific, Bellevue, WA, USA). Photosynthetically active radiation (PAR) was measured throughout the water column using an irradiance sensor $(4 \pi$; QSP-200L; Biospherical Instruments Inc., San Diego, CA, USA). The depth of the euphotic zone $\left(Z_{\mathrm{E}}\right)$ was taken as the penetration depth of $1 \%$ of the surface light. The mixed layer depth $\left(M_{\mathrm{D}}\right)$ was based on the potential density criterion of 0.125 units (Levitus, 1982).

A custom-made flow injection analyzer was used for dissolved inorganic nutrient (e.g., nitrate, phosphate, and silicate) analysis (Gong et al., 2003). Integrated values for the nitrates and other variables assessed in the water column above the $Z_{\mathrm{E}}$ were estimated using the trapezoidal method, in which depth-weighted means are computed from vertical profiles and then multiplied by the $Z_{\mathrm{E}}$ (e.g., Smith and Kemp, 1995). The average nitrate concentration over the $Z_{\mathrm{E}}$ was calculated from the vertically integrated value divided by the $Z_{\mathrm{E}}$. This calculation was adopted to determine the values of the other measured variables.

The fugacity of $\mathrm{CO}_{2}\left(f \mathrm{CO}_{2}\right)$ in the surface waters was calculated from dissolved inorganic carbon (DIC) and total alkalinity (TA) data using a program designed by Lewis and Wallace (1998). For details of the TA and DIC measurements, please see Chou et al. (2007).

\subsection{Biological variables}

The water samples taken for $\mathrm{Chl} a$ analysis were immediately filtered through GF/F filter paper (Whatman, Maidstone, UK; $47 \mathrm{~mm}$ ) and stored in liquid nitrogen. The $\mathrm{Chl} a$ retained on the GF/F filters was quantified fluorometrically (Turner Designs, San Jose, CA, UAA; 10AU-005; Parsons et al., 1984). When applicable, Chl $a$ was converted to carbon units using a $\mathrm{C}: \mathrm{Chl}$ ratio of 52.9 , which was previously estimated from the shelf waters of the ECS (Chang et al., 2003). Surfer 11 (Golden Software, LLC, Golden, CO, USA) was used to estimate the total Chl $a$ content integrated over the $Z_{\mathrm{E}}$ of both the ECS and the CDW (please see below for details). This estimation was also adopted to determine the total quantities for heterotrophic bacteria and zooplankton across the $Z_{\mathrm{E}}$. To compare, total plankton biomass was the summed biomass of 
phytoplankton, bacterioplankton, and zooplankton over the $Z_{\mathrm{E}}$.

Heterotrophic bacteria samples were fixed in paraformaldehyde at a final concentration of $0.2 \%(w / v)$ in the dark for $15 \mathrm{~min}$. They were then immediately frozen in liquid nitrogen and kept at $-80^{\circ} \mathrm{C}$ prior to analysis. The heterotrophic bacteria were stained with the nucleic acid dye SYBR ${ }^{\circledR}$ Green I (emission $=530 \pm 30 \mathrm{~nm}$ ) at a $10^{4}$-fold diluted commercial solution (Molecular Probes, Eugene, OR, USA; Liu et al., 2002). They were then identified and enumerated using a flow cytometer (FACSAria; BD Biosciences, Franklin Lakes, NJ, USA). Known numbers of fluorescent beads (TruCOUNT tubes; BD Biosciences) were simultaneously used to calculate the original cell abundance in each sample. The bacterial abundance was converted to carbon units using a conversion factor of $20 \times 10^{-15} \mathrm{~g} \mathrm{C}$ cell $^{-1}$ (Hobbie et al., 1977; Lee and Fuhrman, 1987).

Zooplankton samples were collected across the whole water column (ranging from 20 to $198 \mathrm{~m}$, depending on the station) at selected stations using a $330 \mu \mathrm{m}$ mesh net with a $160 \mathrm{~cm}$ diameter opening. Upon retrieval of the net, the contents of the cod-end were immediately preserved in $10 \%$ buffered formalin. The zooplankton samples were digitized to extract size information (i.e., body width and length) using the ZooScan integrated system (Hydroptic, L'Isle-jourdain, France), and the size information was used to calculate the ellipsoidal bio-volume of zooplankton (Garcia-Comas, 2010). The biomass (carbon units) of zooplankton was then calculated using the estimated bio-volume following the equations of Alcaraz et al. (2003). To estimate the biomass over the $Z_{\mathrm{E}}$, the total biomass of zooplankton over the whole water column was multiplied by the fraction of the $Z_{\mathrm{E}}$ relative to the depth of the water column at all stations.

The plankton CR, which was calculated as the decrease in dissolved oxygen $\left(\mathrm{O}_{2}\right)$ during dark incubation (Gaarder and Grann, 1927), was measured in samples collected from most stations, with two initial and two dark treatment samples taken from four to six depths (depth intervals of 3, 5, 10, 15, 20 , and/or $25 \mathrm{~m}$ depending on the depth of the water column) within the $Z_{\mathrm{E}}$ at each station. The treatment samples were siphoned into $350 \mathrm{~mL}$ biological oxygen demand (BOD) bottles and incubated for $24 \mathrm{~h}$ in a dark chamber filled with running surface water. The maximum temperature changes were $1.33 \pm 0.81$ and $2.70 \pm 1.43^{\circ} \mathrm{C}$ (mean $\pm \mathrm{SD}$ ) during each incubation in 2009 and 2010, respectively. The concentration of $\mathrm{O}_{2}$ was measured by a direct spectrophotometry method (Pai et al., 1993). The precision of this method was calculated as the root mean square of the difference between the duplicate samples and was found to be 0.02 and $0.03 \mathrm{mg} \mathrm{L}^{-1}$ in 2009 and 2010, respectively. The precision for the initial samples in both periods was $<0.01 \mathrm{mg} \mathrm{L}^{-1}$. The difference in the $\mathrm{O}_{2}$ concentration between the initial and the dark treatment was used to compute the CR. A respiration quotient of 1 was assumed in order to convert the respiration from oxy- gen units to carbon units (Hopkinson, 1985; Parsons et al., 1984).

\section{Results and discussion}

\subsection{Comparison of hydrographic patterns between flooding and non-flooding periods}

In 2010, the Changjiang River began to flood in late May or early June. The mean monthly water discharge was $60527 \mathrm{~m}^{3} \mathrm{~s}^{-1}$, and the suggested discharge rate for flooding was $4-6 \times 10^{4} \mathrm{~m}^{3} \mathrm{~s}^{-1}$, making it the largest recorded flooding of the Changjiang River over the last decade (http: //yu-zhu.vicp.net/). This rate was almost 2 times larger than that recorded in the non-flooding period in July 2009 (33 $955 \mathrm{~m}^{3} \mathrm{~s}^{-1}$; Gong et al., 2011; Yu et al., 2009). During the flood, a tremendous quantity of freshwater was delivered into the ECS, and the low salinity of the sea surface (SSS $\leq 31)$ covered almost two-thirds of the continental shelf (Fig. 1b). The SSS in the ECS during the 2010 flood was significantly lower than during the 2009 non-flooding survey period; the mean $( \pm \mathrm{SD}$ for this and all parameters discussed henceforth) values were $30.32( \pm 3.60)$ and $32.62( \pm 2.07)$, respectively (Table 1). During periods of high discharge from the river, particularly during the summer, the CDW zone is generally distributed within the $60 \mathrm{~m}$ isobath region between the latitudes of 27 and $32^{\circ} \mathrm{N}$ along the coast (e.g., Beardsley et al., 1985; Gong et al., 1996). During the 2010 flood, the CDW dispersed towards the south and east and reached as far as the $100 \mathrm{~m}$ isobath (Fig. 1b). The substantial quantity of freshwater discharged into the ECS is also reflected in the coverage area of the CDW (e.g., Gong et al., 2011); in the 2010 flood, the CDW area $\left(111.7 \times 10^{3} \mathrm{~km}^{2}\right)$ was approximately 6 times larger than in the 2009 non-flooding period $\left(19.0 \times 10^{3} \mathrm{~km}^{2}\right)$.

Although the mean SSS differed significantly between the flooding and non-flooding periods, there was no difference in the temperature of the sea surface (SST; Table 1). The mean values of the SST in $2009(26.8 \pm 1.7)$ and 2010 (and $26.1 \pm 2.2^{\circ} \mathrm{C}$ ) were within the range of the mean SST in the ECS in summer (Chen et al., 2009). The mixed layer depth $\left(M_{\mathrm{D}}\right)$ did not significantly vary between survey periods: $13.7( \pm 7.3) \mathrm{m}$ in 2009 and $11.3( \pm 6.6) \mathrm{m}$ in 2010 (Table 1). However, the average $M_{\mathrm{D}}$ was shallower than documented previously in the summer in the ECS (with a range from 16.8 to $28.2 \mathrm{~m}$; Chen et al., 2009). The euphotic depth $\left(Z_{\mathrm{E}}\right)$ was not significantly deeper in $2009(38.9 \pm 36.4 \mathrm{~m})$ than in 2010 (33.4 $\pm 17.3 \mathrm{~m}$; Table 1$)$. Regarding the $Z_{\mathrm{E}}$, the average $Z_{\mathrm{E}}$ in the ECS was also shallower than in a previous study conducted during the summer (Chen et al., 2009). The shallower $Z_{\mathrm{E}}$ could have been indirectly influenced by the transmittance of the seawater. The average transparency in summer in the ECS over the 2003-2008 period was $81.9 \%$ (C. C. Chen, unpublished data). The average transparency 
Table 1. The mean \pm SD values for the different variables measured in the surface water of the ECS during non-flooding (2009) and flooding (2010) periods with the range of values in parentheses. The mean \pm SD values for stations in the area of the Changjiang diluted water (CDW) region are in brackets. Variables include transparency $\left(\mathrm{CTD}_{\mathrm{TM}} ; \%\right)$, salinity $(\mathrm{SSS})$, temperature $\left(\mathrm{SST} ;{ }^{\circ} \mathrm{C}\right)$, fugacity of $\mathrm{CO}_{2}\left(f \mathrm{CO}_{2} ; \mu \mathrm{atm}\right)$, nitrate concentration $\left(\mathrm{NO}_{3}^{-} ; \mu \mathrm{M}\right)$, phosphate concentration $\left(\mathrm{PO}_{4}^{3-} ; \mu \mathrm{M}\right)$, silicate concentration $\left(\mathrm{SiO}_{4}^{-} ; \mu \mathrm{M}\right)$, chlorophyll $a$ concentration (Chl $a ; \mathrm{mg} \mathrm{Chl} \mathrm{m}^{-3}$ ), bacterial biomass $\left(\mathrm{BB} ; \mathrm{mg} \mathrm{C} \mathrm{m}^{-3}\right)$, and plankton community respiration $\left(\mathrm{CR} ; \mathrm{mg} \mathrm{C} \mathrm{m}^{-3} \mathrm{~d}^{-1}\right.$ ). The euphotic depth $\left(Z_{\mathrm{E}} ; \mathrm{m}\right)$ and mixed layer depth $\left(M_{\mathrm{D}} ; \mathrm{m}\right)$ are also shown for each year. Mann-Whitney rank-sum tests were used to identify temporal differences. For reference, it should be noted that the difference between the CDW zone and the other regions in the ECS in each year was significant for most of the variables $(p<0.05)$, except nitrate and phosphate in 2009.

\begin{tabular}{|c|c|c|}
\hline Variable & 2009 (non-flooding period) & 2010 (flood) \\
\hline \multirow[t]{2}{*}{$Z_{\mathrm{E}}$} & $38.9 \pm 36.4(1.3-190.6)$ & $33.4 \pm 17.3(10.1-82.2)$ \\
\hline & {$[16.8 \pm 7.4]$} & {$[24.8 \pm 10.7]$} \\
\hline \multirow[t]{2}{*}{$M_{\mathrm{D}}$} & $13.7 \pm 7.3(5-37)$ & $11.3 \pm 6.6(4-35)$ \\
\hline & {$[7.3 \pm 3.6]$} & {$[7.9 \pm 2.6]$} \\
\hline \multirow[t]{2}{*}{$\mathrm{CTD}_{\mathrm{TM}}$} & $76.7 \pm 12.2(37.2-86.3)$ & $80.5 \pm 5.4(67.7-88.5)$ \\
\hline & {$[70.0 \pm 4.9]$} & {$[78.4 \pm 4.3]^{* *}$} \\
\hline \multirow[t]{2}{*}{ SSS } & $32.62 \pm 2.07(23.80-34.11)$ & $30.32 \pm 3.60(19.33-34.27)^{*}$ \\
\hline & {$[29.24 \pm 2.52]$} & {$[27.95 \pm 3.03]$} \\
\hline \multirow[t]{2}{*}{ SST } & $26.8 \pm 1.7(23.3-29.6)$ & $26.1 \pm 2.2(21.0-30.0)$ \\
\hline & {$[25.0 \pm 0.9]$} & {$[25.1 \pm 1.7]$} \\
\hline \multirow[t]{2}{*}{$f \mathrm{CO}_{2}$} & $362.9 \pm 101.2(118.7-599.8)$ & $297.6 \pm 79.0(178.7-454.2)^{*}$ \\
\hline & {$[230.4 \pm 105.3]$} & {$[248.6 \pm 54.5]$} \\
\hline \multirow[t]{2}{*}{$\mathrm{NO}_{3}^{-}$} & $2.0 \pm 5.3(0.0-24.3)$ & $6.2 \pm 9.8(0.0-37.6)^{*}$ \\
\hline & {$[4.0 \pm 9.1]$} & {$[10.3 \pm 11.3]^{*}$} \\
\hline \multirow{2}{*}{$\mathrm{PO}_{4}^{3-}$} & $0.13 \pm 0.17(0.00-0.83)$ & $0.17 \pm 0.30(0.00-1.71)$ \\
\hline & {$[0.13 \pm 0.07]$} & {$[0.23 \pm 0.37]$} \\
\hline \multirow[t]{2}{*}{$\mathrm{SiO}_{4}^{-}$} & $5.8 \pm 5.9(1.5-24.5)$ & $6.4 \pm 7.8(0.6-36.4)$ \\
\hline & {$[9.8 \pm 7.2]$} & {$[9.1 \pm 9.2]$} \\
\hline \multirow[t]{2}{*}{ Chl $a$} & $0.98 \pm 1.52(0.12-4.41)$ & $1.26 \pm 1.27(0.03-5.32)$ \\
\hline & {$[2.23 \pm 1.46]$} & {$[1.83 \pm 1.35]$} \\
\hline \multirow[t]{2}{*}{$\mathrm{BB}$} & $39.8 \pm 33.7(10.6-184.8)$ & $20.4 \pm 16.5(3.6-90.2)^{* *}$ \\
\hline & {$[54.9 \pm 39.6]$} & {$[24.4 \pm 18.6]^{* *}$} \\
\hline \multirow[t]{2}{*}{$\mathrm{CR}$} & $73.2 \pm 76.9(2.7-311.9)$ & $105.6 \pm 66.7(10.9-325.3)^{*}$ \\
\hline & {$[172.0 \pm 109.2]$} & {$[142.0 \pm 61.2]$} \\
\hline
\end{tabular}

values of the ECS in 2009 and 2010 were 76.7 and $80.5 \%$, respectively (Table 1). The average transparency for the CDW zone was lower in $2009(70.0 \%)$ and higher high in 2010 (78.4\%) compared to the previous 6-year average $(72.7 \%$; C. C. Chen, unpublished data). This might also explain why the $Z_{\mathrm{E}}$ in the CDW in 2009 was only $16.8 \mathrm{~m}$ (Table 1 ).

These findings suggest that the growth of phytoplankton might be limited by the availability of light, especially in the CDW zone in 2009. Generally, the transparency of the coastal ocean might be low during flooding periods due to the riverine discharge of terrestrial matter. A low transparency value was documented in June 2003 in the ECS, during which the CDW area was $43.1 \times 10^{3} \mathrm{~km}^{2}$ ( $\sim 40 \%$ of the CDW area of the 2010 flood; Chen et al., 2009), and the average transparency values for the ECS and the CDW were 70.9 and $66.0 \%$, respectively (C.C. Chen, unpublished data). The average transparency in the CDW in $2010(78.4 \%)$ was higher than the previous 6-year average $(72.7 \%)$. This could be partially explained by the fact that most large particulates from terrestrial sources might have been confined to and precipitated in the coastal region, not in the expanded CDW region (e.g., Chung et al., 2012). Furthermore, it should also be noted that the 2010 sampling period was 1 month after the beginning of this flood. In estuarine and coastal regions, phytoplankton blooms normally occur within $2-3$ weeks after a heavy rainfall event (e.g., Hsieh et al., 2012; Meng et al., 2016, 2015; Mulholland et al., 2009). Therefore, it is reasonable to speculate that plankton communities were in the late phase of succession in this flood event. The transparency during the 2010 sampling period might have then increased due to organic matter (particulate and dissolved) having been taken up and transferred to higher trophic levels.

In general, a large quantity of dissolved inorganic nutrients is delivered from the Chinese coast to the ECS during the wet season (May to September; Chen et al., 2013, 2009; Gong et al., 1996). A high concentration of nitrates in the fluvial discharge of the Changjiang River was documented in the ECS during the 2010 flood. Furthermore, there was (1) a nega- 
tive linear relationship between SSS and nitrate concentration $\left(r^{2}=0.37, p<0.001, n=37\right)$, (2) a negative linear relationship between SSS and silicate concentration $\left(r^{2}=0.60\right.$, $p<0.001, n=37$ ), and (3) no correlation between SSS and phosphate concentration. The nitrate concentration (Table 1) was significantly higher in the surface waters of the ECS in the $2010(6.2 \pm 9.8 \mu \mathrm{M})$ flood than in the 2009 non-flooding period $(2.0 \pm 5.3 \mu \mathrm{M})$, and similar nitrate concentration differences were perpetuated between sampling times over the $Z_{\mathrm{E}}$ (data not shown). During the 2010 flood, the mean nitrate concentration, either in the surface water or averaged over the $Z_{\mathrm{E}}$, was higher than or comparable to that documented during periods of high riverine discharge in the ECS (Chen et al., 2009; Gong et al., 1996). Nitrate levels reached $37.6 \mu \mathrm{M}$ in the surface water during the 2010 flood, and the highest nitrate concentrations were observed within the CDW (Fig. 1d).

The phosphate concentration in the surface water (Table 1) did not differ between the 2009 non-flooding period $(0.13 \pm 0.17 \mu \mathrm{M})$ and the 2010 flood $(0.17 \pm 0.30 \mu \mathrm{M})$, nor did it differ in the CDW zone between study years $(0.23$ and $0.13 \mu \mathrm{M}$, respectively). However, it should be noted that there was one station with an extremely high phosphate concentration $(1.71 \mu \mathrm{M})$ in the surface water in the CDW zone during the 2010 flood (Fig. 1f), during which the mean molar ratio of nitrate to phosphate $(\mathrm{N} / \mathrm{P})$ over the entire ECS was $22.3 \pm 20.9$. The high N/P molar ratio was even more pronounced in the CDW; it was higher than the Redfield ratio for $\mathrm{N}$ : $\mathrm{P}$ (i.e., 16) at 14 of the 20 stations and averaged at 40.4 $( \pm 22.6)$. This value was comparable to that of the CDW during high riverine flow periods in the ECS in summer (Chen et al., 2006). During the non-flooding period, the N/P molar ratio was lower than 16 with a mean value of $11.5( \pm 20.8)$.

It has been suggested that phytoplankton growth might be regulated by the availability of nutrients or the $\mathrm{N} / \mathrm{P}$ ratio of the available nutrient pool in the ECS (Gong et al., 1996; Harrison et al., 1990). The results of this study indicate that in the 2009 non-flooding period, the phytoplankton biomass might have been regulated by the availability of dissolved inorganic nitrogen to a greater extent than it was during the 2010 flood. The phytoplankton biomass might have also been limited by nitrate and silicate levels in 2010. Based on nutrient levels and the N/P molar ratio, however, phytoplankton growth was more likely limited by phosphate, especially in the CDW zone during the 2010 flood (please refer to Sect. 3.2 for details.). Phytoplankton growth limited by different inorganic nutrients has been observed in estuaries and coastal regions, such as Chesapeake Bay in the United States (Fisher et al., 1992; Harding, 1994). In the ECS, phosphates have been frequently found as a factor limiting phytoplankton growth, especially in the CDW (Chen et al., 2004; Gong et al., 1996; Harrison et al., 1990).

\subsection{Plankton activity associated with the Changjiang River flood}

Following the discharge of fluvial nutrients into the ECS, phytoplankton are generally abundant in the CDW region. The Chl $a$ concentration in the CDW has even reached bloom criteria ( $>20 \mathrm{mg} \mathrm{Chl} \mathrm{m}^{-3}$ ) in past years in the ECS (Chen et al., 2009, 2003). Surprisingly, the phytoplankton biomass was not as high as expected in this study, even though a high nitrate concentration was observed during the 2010 flood. The mean values of Chl $a$ in the surface water of the ECS in 2009 and 2010 were $0.98( \pm 1.52)$ and 1.26 $( \pm 1.27) \mathrm{mg} \mathrm{Chl} \mathrm{m}^{-3}$, respectively (Table 1$)$. However, these mean values were still at the high end of the Chl $a$ concentration range normally documented in the ECS in the midsummer through July-August (Chen et al., 2009). In both periods, the phytoplankton biomass in the surface water was generally higher in the CDW than in other regions of the ECS (Fig. 1g and h). For example, in the 2010 flood, the maximum Chl $a$ value reached $5.32 \mathrm{mg} \mathrm{Chl} \mathrm{m}^{-3}$ in the CDW (Table 1; Fig. 1h). In the 2010 flood, the Chl $a$ values were positively correlated with nitrate and silicate concentrations (all $p<0.001)$, but not phosphate concentrations $(p=0.09)$, in the surface water. The linear relationship between Chl $a$ and phosphate values in the surface water, however, became significant $(p<0.001)$ if one outlier with a markedly high phosphate concentration $(1.71 \mu \mathrm{M})$ was excluded from the analysis (Fig. 1f). In the 2009 non-flooding period, the Chl $a$ concentration was significantly, positively, and linearly correlated with concentrations of all measured nutrients: nitrate, silicate, and phosphate ( $p<0.01$ in all cases).

The spatial distribution pattern of Chl $a$ documented in this study was similar to that found in previous studies of the ECS (Gao and Song, 2005; Gong et al., 2011), and phytoplankton biomass in the surface water (Table 1) or averaged over the $Z_{\mathrm{E}}$ (data not shown) did not differ significantly between 2009 and 2010. In the 2010 flood, primary production (PP) in the surface water was $62.1( \pm 33.8) \mathrm{mg} \mathrm{C} \mathrm{m}^{-3} \mathrm{~d}^{-1}$, which is comparable to values documented in the ECS in summer by Chen et al. (2009). In contrast, the PP: Chl $a$ value was higher in the 2010 flood (27.1 $\left.\pm 17.2 \mathrm{mg} \mathrm{C} \mathrm{mg} \mathrm{Chl}^{-1} \mathrm{~d}^{-1}\right)$ compared to the value documented $\left(19.7 \pm 5.5 \mathrm{mg} \mathrm{Cmg} \mathrm{Chl}^{-1} \mathrm{~d}^{-1}\right)$ by Chen et al. (2009). Gong et al. (2011) estimated that over the past decade, the average rate of carbon fixation during flooding periods was about 3 times higher than during non-flooding periods, and the carbon fixation rate reached $176.0 \times 10^{3} \mathrm{t} \mathrm{C} \mathrm{d}^{-1}$ in the CDW during the 2010 flood (Gong et al., 2011).

In summer, heterotrophic bacterioplankton are generally more abundant in the CDW of the ECS than in other regions (Chen et al., 2006, 2009). Chen et al. (2006) suggested that the growth of bacteria along the coast might be stimulated by the substantial amount of organic matter derived from both autochthonous marine production and fluvial 
Table 2. Total area $\left(\times 10^{3} \mathrm{~km}^{2}\right)$ of the East China Sea (ECS) and Changjiang diluted water (CDW) region (in brackets), as well as bacterial $\left(\mathrm{BB} ; \times 10^{6} \mathrm{~kg} \mathrm{C}\right)$ and zooplankton (Zoo; $\times 10^{6} \mathrm{~kg} \mathrm{C}$ ) biomass over the euphotic depth integrated for the entire ECS and CDW region (in brackets) during non-flooding (2009) and flooding (2010) periods.

\begin{tabular}{lrr}
\hline Variables & $\begin{array}{r}2009 \\
\text { (non-flooding period) }\end{array}$ & $\begin{array}{r}2010 \\
\text { (flood) }\end{array}$ \\
\hline Area & $186.0[19.0]$ & $182.7[111.7]$ \\
BB & $222.5[21.0]$ & $87.3[47.7]$ \\
Zoo & $410.3[6.2]$ & $920.6[560.8]$ \\
\hline
\end{tabular}

runoff. This spatial distribution pattern was also observed in 2009 and 2010. In the 2009 non-flooding period, the mean bacterial biomass in the surface water of the CDW was 77.5 $( \pm 55.7) \mathrm{mg} \mathrm{C} \mathrm{m}^{-3}$, over 2-fold higher than in all other areas $\left(31.0 \pm 18.6 \mathrm{mg} \mathrm{C} \mathrm{m}^{-3}\right)$. Their mean values in the 2010 flood were $24.4( \pm 18.6)$ and $15.0( \pm 11.5) \mathrm{mg} \mathrm{C} \mathrm{m}^{-3}$ in the CDW and other regions, respectively. Further analyses revealed that the bacterial biomass in the surface water was positively and linearly associated with Chl $a$ concentrations in both 2009 $(p<0.01)$ and $2010(p<0.05)$. This finding applies to the values averaged over the $Z_{\mathrm{E}}$ in both periods (both $p<0.01$ ). However, the mean $\mathrm{Chl} a$ concentrations in the surface water were slightly higher in 2010 than in 2009 (Table 1).

In general, an increased amount of organic matter is delivered through fluvial discharge into the ECS during periods of high riverine flow (e.g., Wang et al., 2012). Although these results suggest that the bacterial biomass might be higher in the flooding period than in the non-flooding period, this difference was not verified through the use of averaged bacterial biomass values in this study. The bacterial biomass in the surface water was significantly higher in the 2009 non-flooding period than during the 2010 flood with mean values of $39.8( \pm 33.7)$ and $20.4( \pm 16.5) \mathrm{mg} \mathrm{C} \mathrm{m}^{-3}$, respectively (Table 1 ). The average bacterial biomass over the $Z_{\mathrm{E}}$ was even more pronounced in 2009 than in 2010 (data not shown). However, the total bacterial biomass in the CDW zone was 2 times higher in 2010 than in 2009 with values of 47.7 and $21.0 \times 10^{6} \mathrm{~kg} \mathrm{C}$, respectively (Table 2). A potential cause of the low average bacterial biomass observed during the 2010 flood might be protozoan grazing. Protozoa have been recognized as important microbial grazers in the ECS and in many coastal ecosystems (e.g., Chen et al., 2009, 2003; Sherr and Sherr, 1984). Although protozoan abundance was not measured in this study, a high production rate of nanoflagellates was observed in the southern ECS with mean values of $0.46 \mu \mathrm{g} \mathrm{CL}^{-1} \mathrm{~h}^{-1}$ during periods of high riverine flow (Tsai et al., 2005).

Zooplankton, especially microzooplankton, are amongst the most important contributors to plankton CR (Calbet and Landry, 2004; Hernández-León and Ikeda, 2005; Hopkinson et al., 1989). Unfortunately, microzooplankton were not measured in this study. Instead, zooplankton $(>330 \mu \mathrm{m})$ were sampled across the whole water column. However, the average biomass of zooplankton over the $Z_{\mathrm{E}}$ can still be estimated, and the mean values for the 2010 flood and the 2009 non-flooding period were calculated as $105.7( \pm 144.4)$ and 22.6 ( \pm 25.7$) \mathrm{mg} \mathrm{C} \mathrm{m}^{-3}$, respectively; this difference was statistically significant $(p<0.01)$. The average zooplankton biomass over the $Z_{\mathrm{E}}$ for the CDW zone was 90-fold higher in 2010 than in 2009 (Table 2), suggesting that the flood may have had a significant effect on zooplankton biomass.

\subsection{Effects of Changjiang River flooding on plankton community respiration}

Plankton CR is typically defined as the integrated rate of organic carbon consumption by plankton communities (e.g., Hopkinson et al., 1989; Rowe et al., 1986). In summer, the mean $\mathrm{CR}$ rate in the surface waters of the ECS ranges from 52.2 to $128.4 \mathrm{mg} \mathrm{C} \mathrm{m}^{-3} \mathrm{~d}^{-1}$ (Chen et al., 2006, 2009), and it is significantly correlated with fluvial discharge from the Changjiang River (Chen et al., 2009). In this study, the $\mathrm{CR}$ in the surface water ranged from 2.7 to $311.9 \mathrm{mg} \mathrm{C} \mathrm{m}^{-3} \mathrm{~d}^{-1}$ with a mean value of 73.2 ( \pm 76.9$) \mathrm{mg} \mathrm{C} \mathrm{m}^{-3} \mathrm{~d}^{-1}$ in the 2009 non-flooding period (Table 1). During the 2010 flood, the mean rate in the surface water of $105.6( \pm 66.7) \mathrm{mg} \mathrm{C} \mathrm{m}^{-3} \mathrm{~d}^{-1}$ was significantly higher than in $2009(p<0.01$; Table 1$)$, and CR ranged from 10.9 to $325.3 \mathrm{mg} \mathrm{C} \mathrm{m}^{-3} \mathrm{~d}^{-1}$ (Table 1 ). The $\mathrm{CR}$ rate averaged over the $Z_{\mathrm{E}}$ was statistically similar in both years $(p=0.08)$ with mean values of $76.8( \pm 53.0)$ and 66.8 ( \pm 68.4$) \mathrm{mg} \mathrm{C} \mathrm{m}^{-3} \mathrm{~d}^{-1}$, respectively. In terms of spatial distribution, higher CR rates were mostly observed in the CDW region in both sampling periods, especially along the coast (Fig. 2). Nevertheless, it should be noted that the CDW zone was much larger in 2010 than in 2009.

$\mathrm{CR}$ rates were regressed against the biomass of phytoplankton, heterotrophic bacteria, and zooplankton ( $>330 \mu \mathrm{m})$. However, it should be noted that microzooplankton were not measured in this study and were excluded from our analysis. In this study, CR was significantly correlated with both Chl $a$ concentration and bacterial biomass for both periods in the surface water and when averaged over the $Z_{\mathrm{E}}$ (all $p<0.01$; Fig. 3 ). The contribution of phytoplankton and/or bacterioplankton to CR is substantial in the ECS, even though the relative contribution varies spatially and temporally (Chen et al., 2006, 2009, 2003) Given the importance of phytoplankton and bacterioplankton to $\mathrm{CR}$ rates in both years, as well as their high densities measured herein, it seems likely that these microbial groupings contributed substantially to the CR rate in both 2009 and 2010.

Surprisingly, the mean $\mathrm{Chl} a$ concentration was slightly higher in 2010 than in 2009, though the bacterial biomass was significantly lower in 2010 than in 2009 (Table 1). However, the CR rate was still higher in 2010 than in 2009. In 


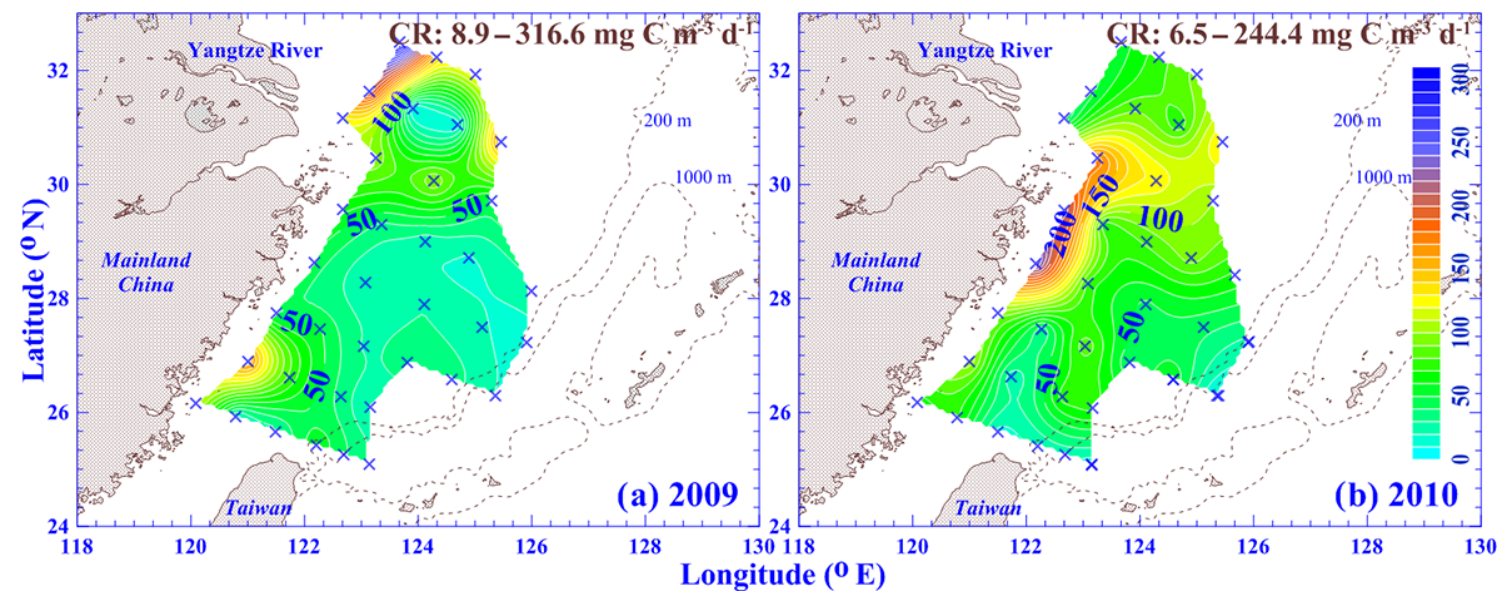

Figure 2. Contour plots of plankton community respiration (CR; $\mathrm{mg} \mathrm{C} \mathrm{m}^{-3} \mathrm{~d}^{-1}$ ) over the euphotic zone of the ECS during (a) non-flooding (2009) and (b) flooding (2010) periods. The contour interval is $10 \mathrm{mg} \mathrm{C} \mathrm{m}^{-3} \mathrm{~d}^{-1}$. The CR range is shown at the top of each panel.
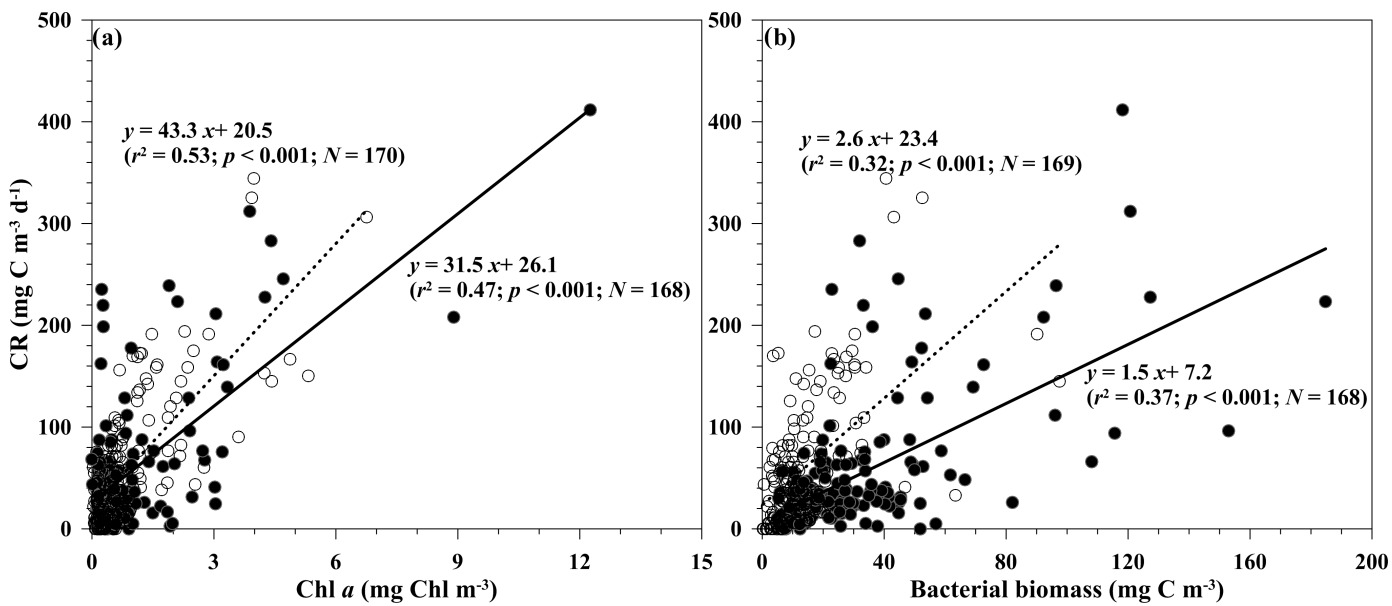

Figure 3. Relationships between plankton community respiration (CR; $\mathrm{mg} \mathrm{Cm}^{-3} \mathrm{~d}^{-1}$ ), (a) chlorophyll $a$ concentration (Chl $a$; $\mathrm{mg} \mathrm{Chl} \mathrm{m}{ }^{-3}$ ), and (b) bacterial biomass $\left(\mathrm{mg} \mathrm{C} \mathrm{m}^{-3}\right)$ for all data from non-flooding (2009; o) and flooding (2010; •) periods. Linear regressions of the data from 2009 (solid lines) and 2010 (dashed lines), as well as the respective $r^{2}$ and $p$ values, have also been included.

a further analysis, the differences (i.e., 2010 minus 2009) in the average CR, Chl $a$ concentration, and bacterial biomass over the $Z_{\mathrm{E}}$ at the same station were calculated. The extent of such differences in CR was significantly related to differences in Chl $a$ concentration $(p<0.001)$ and bacterial biomass $(p<0.01$; Fig. 4$)$. The linear relationships were also statistically significant if the values of the differences in the surface water were used (all $p<0.01$; data not shown). Among the positive CR difference values (i.e., 20 of 33), 15 stations were also characterized by positive differences in Chl aconcentrations; only 2 stations had positive differences in bacterial biomass. Interestingly, the stations with positive Chl $a$ values in terms of concentration difference were mostly located within the CDW region in 2010, with the exception of the CDW in 2009. These results suggest that the higher CR in the 2010 flood might be attributed to phytoplankton, especially in the CDW. The mean Chl $a$ concentra- tion was only slightly higher in 2010 than in 2009 . Therefore, it is reasonable to speculate that the differences in the CR rate in both periods might have been partially caused by variation in the composition of the phytoplankton communities. Although the CR attributed to different components of the phytoplankton community was not measured in this study, it has been documented elsewhere; for instance, dinoflagellates have higher carbon-specific respiration rates than many other phytoplankton types (e.g., Lopez-Sandoval et al., 2014).

In addition, zooplankton might also be amongst the potential contributors to the higher CR rate observed in 2010 than in 2009. As stated above, the biomass of zooplankton was significantly higher in 2010 than in 2009. However, the linear relationships between CR and zooplankton biomass over the $Z_{\mathrm{E}}$ were not statistically significant in 2009 or 2010. To further explore how plankton communities contributed to $\mathrm{CR}$, the $\mathrm{CR}$ rate was regressed against the to- 

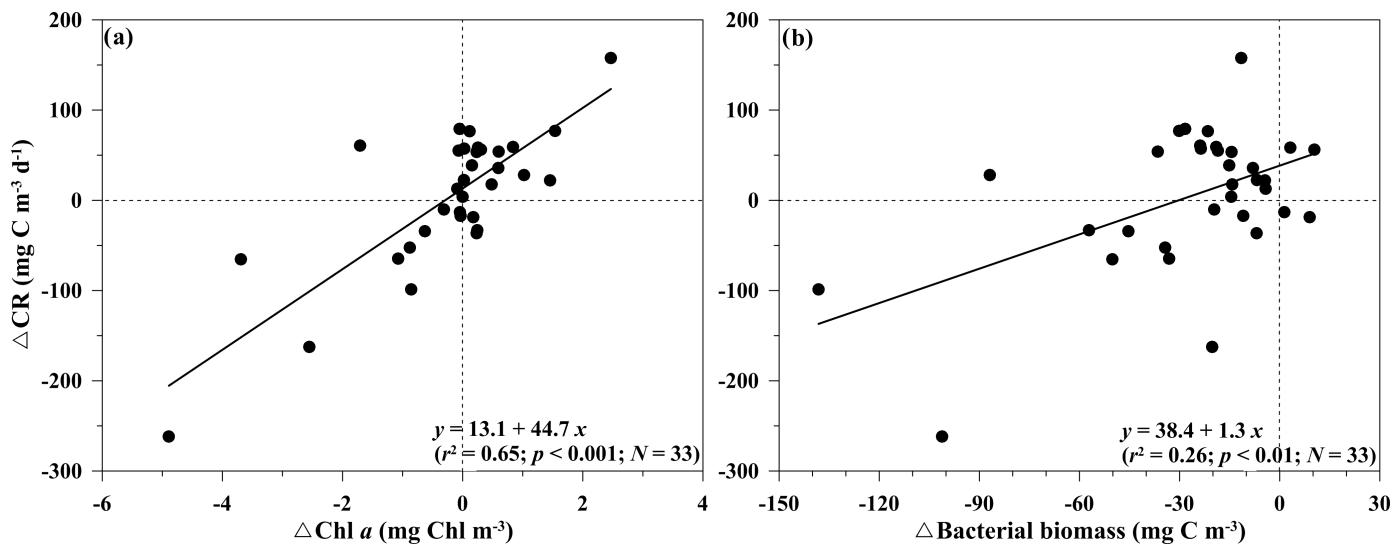

Figure 4. Differences $(\Delta)$ between 2009 and 2010 in plankton community respiration (CR; $\mathrm{mg} \mathrm{C} \mathrm{m}^{-3} \mathrm{~d}^{-1}$ ) versus (a) chlorophyll $a$ $\left(\mathrm{Chl} a ; \mathrm{mg} \mathrm{Chl} \mathrm{m}^{-3}\right)$ and (b) bacterial biomass $\left(\mathrm{mg} \mathrm{C} \mathrm{m}^{-3}\right)$ over the euphotic zone at the same station. The $r^{2}$ and $p$ values have been shown for the best-fit linear regression line (solid line). For reference, the vertical and horizontal dashed lines represent inter-year differences of zero (i.e., $\Delta=0$ ).

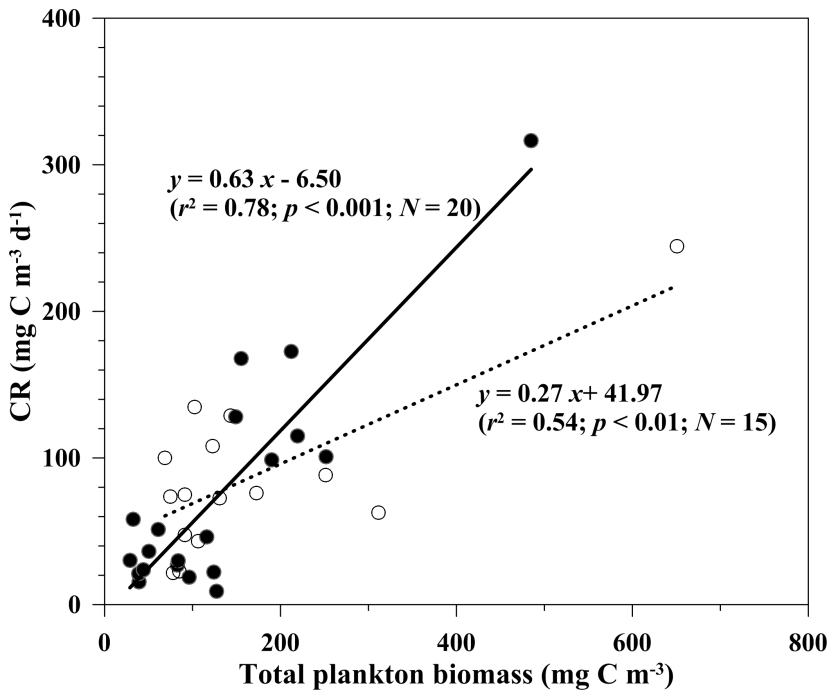

Figure 5. Relationship between plankton community respiration (CR) and total plankton biomass (expressed per carbon unit) over the $Z_{\mathrm{E}}$ in 2009 (o; solid line) and 2010 ( $\bullet$; dashed line). The respective $r^{2}$ and $p$ values are shown for each linear regression line. The total plankton biomass is the summed biomass of phytoplankton, bacterioplankton, and zooplankton. Please refer to the "Materials and Methods" section for details on the carbon conversion for plankton communities.

tal plankton biomass (i.e., summed biomass of phytoplankton, bacterioplankton, and zooplankton) for both periods, and the linear relationships between $\mathrm{CR}$ and the total plankton biomass $\left(\mathrm{mg} \mathrm{C} \mathrm{m}^{-3}\right)$ over the $Z_{\mathrm{E}}$ were significant in both $2009(p<0.001)$ and 2010 ( $p<0.01$; Fig. 5).

Similarly significant relationships between CR and total planktonic biomass have also been observed in the summer in the ECS, and phytoplankton and bacterioplankton might be the most important components contributing to $\mathrm{CR}$ at such

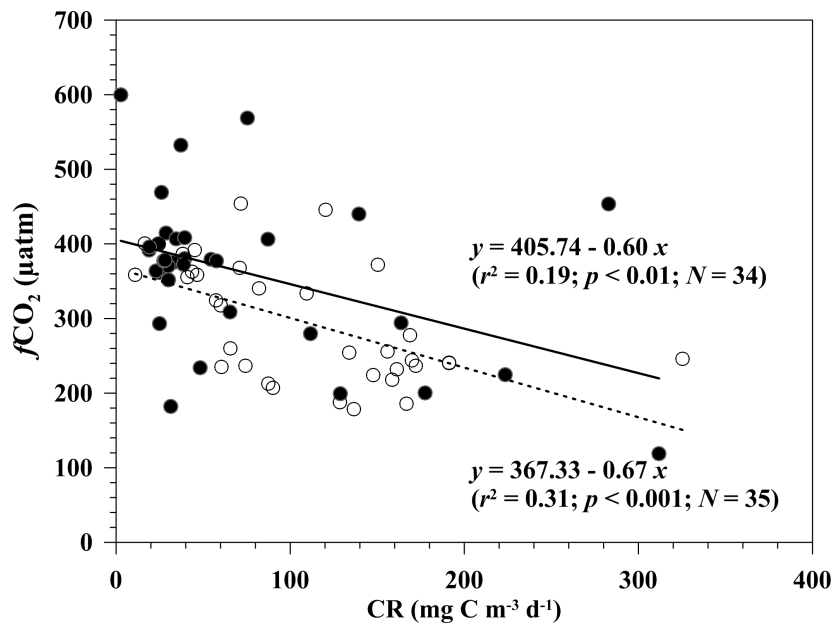

Figure 6. Relationships between the fugacity of $\mathrm{CO}_{2}\left(f \mathrm{CO}_{2}\right)$ and plankton community respiration (CR) in the surface water in 2009 (॰; solid line) and 2010 ( $\bullet$; dashed line). The respective $r^{2}$ and $p$ values are shown for each linear regression line.

times (Chen et al., 2006). In this study, the autotrophic plankton biomass (i.e., phytoplankton) accounted for 41.3 and $45.6 \%$ of the total planktonic biomass in 2009 and 2010, respectively. As for the heterotrophic plankton biomass, bacterioplankton were attributed to 38.7 and $11.3 \%$ and zooplankton contributed 20.0 and $43.1 \%$ of the total plankton biomass in 2009 and 2010, respectively. This suggests that phytoplankton and bacterioplankton might be the most important components contributing to $\mathrm{CR}$ in the 2009 non-flooding period. In contrast, during the 2010 flood, the CR rate might have been mostly driven by phytoplankton and zooplankton metabolic activity.

All such conjectures are based on stocks, and biomass might not be directly related to the concurrent $\mathrm{CR}$ rate. By 


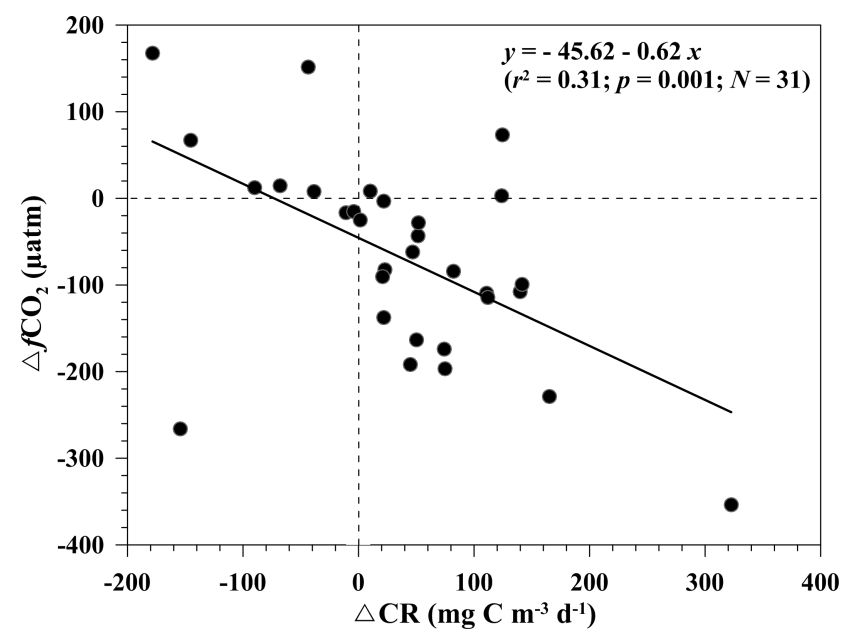

Figure 7. Differences $(\Delta)$ between 2009 and 2010 in $f \mathrm{CO}_{2}$ ( $\mu$ atm) and plankton community respiration $\left(\mathrm{CR} ; \mathrm{mg} \mathrm{C} \mathrm{m}^{-3} \mathrm{~d}^{-1}\right)$ in the surface water at the same station. For reference, the vertical and horizontal dashed lines represent interannual differences of zero (i.e., $\Delta=0)$.

using physiological and allometric relationships of variant plankton communities, the plankton CR rate could be estimated from stock values, and significant correlations have indeed been found between measured and estimated rates (Chen et al., 2009). Furthermore, it should be noted that microzooplankton might be another important contributor to $\mathrm{CR}$, though they were unfortunately not assessed herein.

\subsection{Implications of plankton community respiration on coastal ecosystems of the ECS}

A further comparative analysis was conducted to determine whether the CR rate affected the fugacity of $\mathrm{CO}_{2}\left(f \mathrm{CO}_{2}\right)$ in the seawater. In 2009 , the $f \mathrm{CO}_{2}$ in the surface water was in the range of $118.7-599.8 \mu \mathrm{atm}$ with mean values of $362.9 \pm 101.2 \mu \mathrm{atm}$ (Table 1). This mean value is close to the mean $(369.6 \mu \mathrm{atm})$ observed in the ECS in August in prior years (Chen et al., 2006). In the 2010 flood, the mean value $(297.6 \mu \mathrm{atm})$ of $f \mathrm{CO}_{2}$ in the surface water was significantly lower than in 2009 and ranged from 178.7 to $454.2 \mu$ atm (Table 1). It is well known that $f \mathrm{CO}_{2}$ is temperature dependent, and it increases as the temperature increases (e.g., Goyet et al., 1993). The effect of temperature on the large variation in $f \mathrm{CO}_{2}$ observed between the 2009 non-flooding period and the 2010 flood was trivial; the SST difference of $0.7^{\circ} \mathrm{C}$ between 2009 and 2010 would only equal an $f \mathrm{CO}_{2}$ decrease of approximately $10 \mu \mathrm{atm}$ (Table 1 ).

The effect of freshwater input on $f \mathrm{CO}_{2}$ in the surface water in the ECS has also been suggested to be relatively minor compared to the interannual variation in $f \mathrm{CO}_{2}$ (Chen et al., 2013). To evaluate this, conservative mixing was applied by using TA and DIC data between freshwater and seawater end-members. Provided that the proportional contributions from freshwater and seawater end-members are $f_{1}$ and $f_{2}$ $\left(f_{1}+f_{2}=1\right)$, respectively, the conservative mixing TA and DIC values for a given water sample can be expressed by the following equations:

$\mathrm{TA}_{\text {mix }}=\mathrm{TA}_{\mathrm{fw}} \times f_{1}+\mathrm{TA}_{\mathrm{sw}} \times f_{2}$,

$\mathrm{DIC}_{\text {mix }}=\mathrm{DIC}_{\mathrm{fw}} \times f_{1}+\mathrm{DIC}_{\mathrm{sw}} \times f_{2}$,

where the subscripts "mix", "fw", and "sw" represent the values of conservative mixing, freshwater, and seawater end-members, respectively. The TA and DIC data reported by Zhai et al. (2007) for the Changjiang River in summer were used as the freshwater end-members (both $\mathrm{TA}_{\mathrm{fw}}$ and $\mathrm{DIC}_{\mathrm{fw}}=1743 \mu \mathrm{mol} \mathrm{kg}{ }^{-1}$ ), and the surface data at station $\mathrm{K}$ in July 2009 and 2010 were chosen to represent the seawater end-members $\left(\mathrm{TA}_{\mathrm{sw}}=2241 \mu \mathrm{mol} \mathrm{kg}-1\right.$ and $\mathrm{DIC}_{\mathrm{sw}}=1909 \mu \mathrm{mol} \mathrm{kg}^{-1}$ in $2009 ; \mathrm{TA}_{\mathrm{sw}}=2240 \mu \mathrm{mol} \mathrm{kg}{ }^{-1}$ and $\mathrm{DIC}_{\mathrm{sw}}=1904 \mu \mathrm{mol} \mathrm{kg}{ }^{-1}$ in 2010). Subsequently, the hypothetical $f \mathrm{CO}_{2}$ from conservative mixing was calculated from the $\mathrm{TA}_{\text {mix }}$ and $\mathrm{DIC}_{\text {mix }}$ data using CO2SYS version 2.1 (Pierrot et al., 2006), in which the carbonic acid dissociation constants were adopted from Mehrbach et al. (1973) and refitted by Dickson and Millero (1987). The uncertainty in this simulation mainly derives from errors in the estimations of $\mathrm{TA}_{\mathrm{mix}}$ and $\mathrm{DIC}_{\mathrm{mix}}$. Assuming that the errors in the calculated $\mathrm{TA}_{\text {mix }}$ and $\mathrm{DIC}_{\text {mix }}$ are $\pm 5 \mu \mathrm{mol} \mathrm{kg}{ }^{-1}$, this may result in an uncertainty of $\pm 13 \mu$ atm in the simulated $f \mathrm{CO}_{2}$. The simulated results show that the effect of mixing freshwater and seawater on $f \mathrm{CO}_{2}$ was nearly the same in both periods. However, a large variation in $f \mathrm{CO}_{2}$ in the surface water was estimated; it varied from 375.4 to $439.8 \mu$ atm as salinity varied from 20.38 to 33.96 . This finding implies that surface water $f \mathrm{CO}_{2}$ in the ECS might increase dramatically, especially during the devastating flood of 2010 where low SSS $(\leq 31)$ characterized almost $70 \%$ of the ECS shelf (Fig. 1b). However, in the 2010 flood, surface water with low $f \mathrm{CO}_{2}$ was observed in the ECS. Therefore, vigorous photosynthetic processes might be a potential cause of the reduction in $f \mathrm{CO}_{2}$ in the surface water during periods of flooding. Compared to PP values observed in summer in the ECS in previous years (Chen et al., 2009), PP was indeed high during the 2010 flood (Table 1; Chen et al., 2009). Gong et al. (2011) also estimated that over the past decade, the carbon fixation rate during flooding was about 3 times higher than during non-flooding periods. However, no significant correlation was found between $f \mathrm{CO}_{2}$ and $\mathrm{PP}$ in the 2010 flood, though this may simply be due to the small sample size for PP. Nevertheless, $f \mathrm{CO}_{2}$ was significantly correlated with $\mathrm{Chl} a$ concentration in the pooled 2010 flood dataset $(p<0.001)$. This significant relationship indirectly supports the hypothesis that the reduction in $f \mathrm{CO}_{2}$ in the 2010 flood might be associated with vigorous phytoplankton metabolic activity. Furthermore, negative linear relationships were observed between $f \mathrm{CO}_{2}$ and $\mathrm{CR}$ in the surface water during both the 2009 non-flooding period $(p<0.01)$ 
and the 2010 flood ( $p<0.001$; Fig. 6). Significant linear relationships were also found using pooled data from each period (all $p<0.001$ ). CR has been assumed to be an integrated response of overall plankton activity. These results imply that $f \mathrm{CO}_{2}$ in the surface water (or the entire water column) is related to plankton activities. To explore the variation in $f \mathrm{CO}_{2}$ between the non-flooding and flooding period, the difference in $f \mathrm{CO}_{2}$ and $\mathrm{CR}$ at the same station was estimated. Surprisingly, a negative linear relationship was found between the difference in $f \mathrm{CO}_{2}$ and $\mathrm{CR}$ for the flooding and non-flooding periods ( $p=0.001 ;$ Fig. 7). As previously stated, compared to the 2009 non-flooding period, the increase in the CR rate in the 2010 flood might be associated with the increase in phytoplankton biomass (Fig. 4a). These results indicate that the significant amount of $f \mathrm{CO}_{2}$ absorption in the 2010 flood was related to the strength of plankton activity, particularly phytoplankton at stations that were not characterized by low SSS in the 2009 non-flooding period.

\section{Conclusions}

Riverine runoff has a profound effect on organic carbon production and consumption in coastal ecosystems across the globe, and these effects will become even more pronounced as storm frequency and magnitude increase in the coming decades. During the 2010 flooding of the Changjiang River, a large quantity of freshwater was discharged into the ECS, and the CDW zone covered almost two-thirds of the continental shelf; this represents a 6-fold larger area than during a more typical non-flooding period (2009). Higher nitrate concentrations, mostly in the river's fluvial discharge, were also measured in the ECS during the flood. Although the phytoplankton biomass showed no significant difference between 2009 and 2010, the bacterial biomass in the surface water was significantly higher in the 2009 non-flooding period. Despite this, CR was still higher during the 2010 flood than in the 2009 non-flooding period. The temporal difference (2010 minus 2009) in CR was significantly related to the respective differences in $\mathrm{Chl} a$ concentration, suggesting that the higher CR in the 2010 flood might have been attributed to a higher biomass of phytoplankton, especially at stations located within the CDW region (most of which were not characterized by low SSS in the 2009 non-flooding period). In addition to phytoplankton, zooplankton ( $>330 \mu \mathrm{m})$ may have also contributed significantly to the high $\mathrm{CR}$ rate observed in the 2010 flood. This could be evidenced by the fact that the zooplankton biomass in 2010 accounted for $43.1 \%$ of the total plankton biomass. Finally, a negative linear relationship was found between the temporal differences (i.e., 2010 minus $2009)$ in $\mathrm{CR}$ vs. $f \mathrm{CO}_{2}$. This finding implies that a tremendous quantity of $f \mathrm{CO}_{2}$ was taken up during phytoplankton photosynthesis during the flood period. Overall, these results suggest that plankton activity increased due to the substantial input of dissolved inorganic nutrients discharged by the river during the flood. This effect was especially pronounced at stations not previously characterized by low SSS, indicating that the effects of flooding on the ECS shelf ecosystem might be scaled to the magnitude of the flood.

Data availability. Data are available upon request to the corresponding author.

Competing interests. The authors declare that they have no conflict of interest.

Acknowledgements. This study is part of a multidisciplinary program entitled "Effects of Global Change on Ocean Biogeochemistry and Ecosystems in the Seas Surrounding Taiwan in the Northwest Pacific" (ECOBEST), which is supported by Taiwan's Ministry of Science and Technology (MOST) under grants MOST 104-2611-M-003-001 and MOST 105-2119-M-003-007-MY2 to C.-C. Chen. We are further indebted to the officers and crew of the Ocean Researcher $I$ for their assistance during the research cruise. The authors are also grateful to T. C. Malone at Horn Point Laboratory, UMCES and three anonymous reviewers for providing valuable and constructive comments that improved the manuscript. Finally, we would like to thank Anderson Mayfield for his assistance with the English proofreading of the final versions of the manuscript. This article was subsidized by the National Taiwan Normal University (NTNU), Taiwan, ROC.

Edited by: C. Robinson

Reviewed by: three anonymous referees

\section{References}

Alcaraz, M., Saiz, E., Calbet, A., Trepat, I., and Broglio, E.: Estimating zooplankton biomass through image analysis, Mar. Biol., 143, 307-315, 2003.

Beardsley, R. C., Limeburner, R., Yu, H., and Cannon, G. A.: Discharge of the Changjiang (Yangtze River) into the East China Sea, Cont. Shelf Res., 4, 57-76, 1985.

Calbet, A. and Landry, M. R.: Phytoplankton growth, microzooplankton grazing, and carbon cycling in marine systems, Limnol. Oceanogr., 49, 51-57, 2004.

Chang, J., Shiah, F. K., Gong, G. C., and Chiang, K. P.: Cross-shelf variation in carbon-to-chlorophyll $a$ ratios in the East China Sea, summer 1998, Deep-Sea Res. Pt. II, 50, 1237-1247, 2003.

Chen, C.-C., Shiah, F. K., Gong, G. C., and Chiang, K. P.: Planktonic community respiration in the East China Sea: importance of microbial consumption of organic carbon, Deep-Sea Res. Pt. II, 50, 1311-1325, 2003.

Chen, C.-C., Shiah, F. K., Chiang, K. P., Gong, G. C., and Kemp, W. M.: Effects of the Changjiang (Yangtze) River discharge on planktonic community respiration in the East China Sea, J. Geophys. Res.-Oceans, 114, C03005, doi:10.1029/2008jc004891, 2009. 
Chen, C.-C., Gong, G.-C., Shiah, F.-K., Chou, W.-C., and Hung, C.-C.: The large variation in organic carbon consumption in spring in the East China Sea, Biogeosciences, 10, 2931-2943, doi:10.5194/bg-10-2931-2013, 2013.

Chen, C.-C., Chiang, K. P., Gong, G. C., Shiah, F. K., Tseng, C. M., and Liu, K. K.: Importance of planktonic community respiration on the carbon balance of the East China Sea in summer, Global Biogeochem. Cy., 20, Gb4001, doi:10.1029/2005gb002647, 2006.

Chen, C. S., Zhu, J. R., Beardsley, R. C., and Franks, P. J. S.: Physical-biological sources for dense algal blooms near the Changjiang River, Geophys. Res. Lett., 30, 1515-1518, 2003.

Chen, Y. L. L., Chen, H. Y., Gong, G. C., Lin, Y. H., Jan, S., and Takahashi, M.: Phytoplankton production during a summer coastal upwelling in the East China Sea, Cont. Shelf Res., 24, 1321-1338, 2004.

Chou, W. C., Sheu, D. D., Chen, C. T. A., Wen, L. S., Yang, Y., and Wei, C. L.: Transport of the South China Sea subsurface water outflow and its influence on carbon chemistry of Kuroshio waters off southeastern Taiwan, J. Geophys. Res.-Oceans, 112, C12008, doi:10.1029/2007jc004087, 2007.

Christensen, J. H. and Christensen, O. B.: Climate modelling: Severe summertime flooding in Europe, Nature, 421, 805-806, 2003.

Chung, C. C., Gong, G. C., and Hung, C. C.: Effect of Typhoon Morakot on microphytoplankton population dynamics in the subtropical Northwest Pacific, Mar. Ecol.-Prog. Ser., 448, 39-49, 2012.

Chung, C. C., Huang, C. Y., Gong, G. C., and Lin, Y. C.: Influence of the Changjiang River Flood on Synechococcus Ecology in the Surface Waters of the East China Sea, Microb. Ecol., 67, 273285, 2014

Dagg, M., Benner, R., Lohrenz, S., and Lawrence, D.: Transformation of dissolved and particulate materials on continental shelves influenced by large rivers: plume processes, Cont. Shelf Res., 24, 833-858, 2004.

Dickson, A. G. and Millero, F. J.: A Comparison of the EquilibriumConstants for the Dissociation of Carbonic-Acid in Seawater Media, Deep-Sea Res, 34, 1733-1743, 1987.

Fisher, T. R., Peele, E. R., Ammerman, J. W., and Harding, L. W., Jr.: Nutrient limitation of phytoplankton in Chesapeake Bay, Mar. Ecol.-Prog. Ser., 82, 51-63, 1992.

Gaarder, T. and Grann, H. H.: Investigations of the production of plankton in the Oslo Fjord, Rapport et Proces-Verbaux des Reunions, Conseil Permanent International pour l'Exploration de la Mer, 42, 3-31, 1927.

Gao, X. L. and Song, J. M.: Phytoplankton distributions and their relationship with the environment in the Changjiang Estuary, China, Mar. Pollut. Bull., 50, 327-335, 2005.

Garcia-Comas, C.: Short manual to work with the ZooScan, Zooprocess version 6.16, http://www.zooscan.com (last access: 18 May 2017), 2010.

Gong, G.-C., Chen, Y.-L. L., and Liu, K.-K.: Chemical hydrography and chlorophyll $a$ distribution in the East China Sea in summer: implication in nutrient dynamics, Cont. Shelf Res., 16, 15611590, 1996.

Gong, G.-C., Wen, Y.-H., Wang, B.-W., and Liu, G.-J.: Seasonal variation of chlorophyll $a$ concentration, primary production and environmental conditions in the subtropical East China Sea, Deep-Sea Res. Pt. II, 50, 1219-1236, 2003.

Gong, G. C., Liu, K. K., Chiang, K. P., Hsiung, T. M., Chang, J., Chen, C. C., Hung, C. C., Chou, W. C., Chung, C. C., Chen, H. Y., Shiah, F. K., Tsai, A. Y., Hsieh, C. H., Shiao, J. C., Tseng, C. M., Hsu, S. C., Lee, H. J., Lee, M. A., Lin, I. I., and Tsai, F. J.: Yangtze River floods enhance coastal ocean phytoplankton biomass and potential fish production, Geophys. Res. Lett., 38, L13603, doi:10.1029/2011GL047519, 2011.

Goyet, C., Millero, F. J., Poisson, A., and Shafer, D. K.: Temperature dependence of $\mathrm{CO}_{2}$ fugacity in seawater, Mar. Chem., 44, 205-219, 1993.

Harding Jr., L. W.: Long-term trends in the distribution of phytoplankton in Chesapeake Bay: roles of light, nutrients and streamflow, Mar. Ecol.-Prog. Ser., 104, 267-291, 1994.

Harrison, P. J., Hu, M. H., Yang, Y. P., and Lu, X.: Phosphate limitation in estuarine and coastal waters of China, J. Exp. Mar. Biol. Ecol., 140, 79-87, 1990.

Hedges, J. I., Keil, R. G., and Benner, R.: What happens to terrestrial organic matter in the ocean?, Org. Geochem., 27, 195-212, 1997.

Hedges, J. I., Cowie, G. L., Richey, J. E., Quay, P. D., Benner, R., Strom, M., and Forsberg, B. R.: Origins and processing of organic-matter in the Amazon River as indicated by carbohydrates and amino-acids, Limnol. Oceanogr., 39, 743-761, 1994.

Hernández-León, S. and Ikeda, T.: A global assessment of mesozooplankton respiration in the ocean, J. Plankton Res., 27, 153-158, 2005.

Hobbie, J. E., Daley, R. J., and Jasper, S.: Use of nuclepore filters for counting bacteria by fluorescence microscopy, Appl. Environ. Microbiol., 33, 1225-1228, 1977.

Hopkinson Jr., C. S.: Shallow-water benthic and pelagic metabolism: evidence of heterotrophy in the nearshore Georgia Bight, Mar. Biol., 87, 19-32, 1985.

Hopkinson Jr., C. S., Sherr, B., and Wiebe, W. J.: Size fractionated metabolism of coastal microbial plankton, Mar. Ecol.-Prog. Ser., 51, 155-166, 1989.

Hsieh, W. C., Chen, C. C., Shiah, F. K., Hung, J. J., Chiang, K. P., Meng, P. J., and Fan, K. S.: Community metabolism in a tropical lagoon: carbon cycling and autotrophic ecosystem induced by a natural nutrient pulse, Environ. Eng. Sci., 29, 776-782, 2012.

Knox, J. C.: Large Increases in Flood Magnitude in Response to Modest Changes in Climate, Nature, 361, 430-432, 1993.

Lee, S. and Fuhrman, J. A.: Relationship between biovolume and biomass of naturally derived marine bacterioplankton, Appl. Environ. Microbiol., 53, 1298-1303, 1987.

Levitus, S.: Climatological atlas of the word ocean, NOAA professional paper No. 13, US Government Printing Office, Washington, DC, 173 pp., 1982.

Lewis, E. and Wallace, D. W. R.: Program developed for $\mathrm{CO}_{2}$ system calculations, Rep. ORNL/CDIAC-105, Carbon Dioxide Inf Anal. Cent., Oak Ridge Natl. Lab., Oak Ridege, Tenn., 1998.

Liu, H. B., Suzukil, K., Minami, C., Saino, T., and Watanabe, M.: Picoplankton community structure in the subarctic Pacific Ocean and the Bering Sea during summer 1999, Mar. Ecol.-Prog. Ser., 237, 1-14, 2002.

Liu, K.-K., Gong, G.-C., Wu, C.-R., and Lee, H.-J.: The Kuroshio and the East China Sea, in: Carbon and Nutrient Fluxes in Continental Margins: A Global Synthesis, edited by: Liu, K. K., Atkin- 
son, L., Quiñones, R., and TalaueMcManus, L., Springer, Berlin, 124-146, 2010.

Lopez-Sandoval, D. C., Rodriguez-Ramos, T., Cermeno, P., Sobrino, C., and Maranon, E.: Photosynthesis and respiration in marine phytoplankton: Relationship with cell size, taxonomic affiliation, and growth phase, J. Exp. Mar. Biol. Ecol., 457, 151-159, 2014.

Malone, T. C. and Ducklow, H. W.: Microbial biomass in the coastal plume of Chesapeake Bay : phytoplankton-bacterioplankton relationships, Limnol. Oceanogr., 35, 296-312, 1990.

Mehrbach, C., Culberson, C. H., Hawley, J. E., and Pytkowicz, R. M.: Measurement of Apparent Dissociation-Constants of Carbonic-Acid in Seawater at Atmospheric-Pressure, Limnol. Oceanogr., 18, 897-907, 1973.

Meng, P.-J., Tew, K. S., Hsieh, H.-Y., and Chen, C.-C.: Relationship between magnitude of phytoplankton blooms and rainfall in a hyper-eutrophic lagoon: A continuous monitoring approach, Mar. Pollut. Bull., in press, doi:10.1016/j.marpolbul.2016.12.040, 2016.

Meng, P. J., Lee, H. J., Tew, K. S., and Chen, C. C.: Effect of a rainfall pulse on phytoplankton bloom succession in a hypereutrophic subtropical lagoon, Mar. Freshwater Res., 66, 60-69, 2015.

Milly, P. C. D., Wetherald, R. T., Dunne, K. A., and Delworth, T. L.: Increasing risk of great floods in a changing climate, Nature, 415, 514-517, 2002.

Mulholland, M. R., Morse, R. E., Boneillo, G. E., Bernhardt, P. W., Filippino, K. C., Procise, L. A., Blanco-Garcia, J. L., Marshall, H. G., Egerton, T. A., Hunley, W. S., Moore, K. A., Berry, D. L., and Gobler, C. J.: Understanding causes and impacts of the dinoflagellate, Cochlodinium polykrikoides, blooms in the Chesapeake Bay, Estuar. Coast., 32, 734-747, 2009.

Müller-Karger, F. E., McClain, C. R., and Richardson, P. L.: The dispersal of the Amazon's water, Nature, 333, 56-59, 1988.

Nixon, S. W., Ammerman, J. W., Atkinson, L. P., Berounsky, V. M., Billen, G., Boicourt, W. C., Boynton, W. R., Church, T. M., Ditoro, D. M., Elmgren, R., Garber, J. H., Giblin, A. E., Jahnke, R. A., Owens, N. J. P., Pilson, M. E. Q., and Seitzinger, S. P.: The fate of nitrogen and phosphorus at the land-sea margin of the North Atlantic Ocean, Biogeochem., 35, 141-180, 1996.

Pai, S.-C., Gong, G.-C., and Liu, K.-K.: Determination of dissolved oxygen in seawater by direct spectrophotometry of total iodine, Mar. Chem., 41, 343-351, 1993.
Palmer, T. N. and Ralsanen, J.: Quantifying the risk of extreme seasonal precipitation events in a changing climate, Nature, 415, 512-514, 2002.

Parsons, T. R., Maita, Y., and Lalli, C. M.: A manual of chemical and biological methods for seawater analysis, Pergamon Press, New York, 173 pp., 1984.

Pierrot, D. E., Levis, E., and Wallace, D. W. R.: MS Excel Program Developed for $\mathrm{CO}_{2}$ System Calculations, Carbon Dioxide Information Analysis Center, Oak Ridge National Laboratory, US Department of Energy, 2006.

Rowe, G. T., Smith, S., Falkowski, P., Whitledge, T., Theroux, R., Phoel, W., and Ducklow, H.: Do continental shelves export organic matter?, Nature, 324, 559-561, 1986.

Sherr, E. B. and Sherr, B. F.: Role of heterotrophic protozoa in carbon and energy flow in aquatic ecosystems, in: Current perspectives in microbial ecology, edited by: Klug, M. J. and Reddy, C. A., American society for microbiology, Washington, D.C., 412423, 1984

Smith, E. M. and Kemp, W. M.: Seasonal and regional variations in plankton community production and respiration for the Chesapeake Bay, Mar. Ecol.-Prog. Ser., 116, 217-231, 1995.

Tian, R. C., Hu, F. X., and Martin, J. M.: Summer nutrient fronts in the Changjiang (Yangtze River) Estuary, Estuar. Coast. Shelf Sci., 37, 27-41, 1993.

Tsai, A. Y., Chiang, K. P., Chang, J., and Gong, G. C.: Seasonal diel variations of picoplankton and nanoplankton in a subtropical western Pacific coastal ecosystem, Limnol. Oceanogr., 50, 12211231, 2005.

Wang, X. C., Ma, H. Q., Li, R. H., Song, Z. S., and Wu, J. P.: Seasonal fluxes and source variation of organic carbon transported by two major Chinese Rivers: The Yellow River and Changjiang (Yangtze) River, Global Biogeochem. Cy., 26, Gb2025, doi:10.1029/2011gb004130, 2012.

$\mathrm{Xu}, \mathrm{K} . \mathrm{H}$. and Milliman, J. D.: Seasonal variations of sediment discharge from the Yangtze River before and after impoundment of the Three Gorges Dam, Geomorphology, 104, 276-283, 2009.

Yu, F. L., Chen, Z. Y., Ren, X. Y., and Yang, G. F.: Analysis of historical floods on the Yangtze River, China: Characteristics and explanations, Geomorphology, 113, 210-216, 2009.

Zhai, W. D., Dai, M. H., and Guo, X. G.: Carbonate system and $\mathrm{CO}_{2}$ degassing fluxes in the inner estuary of Changjiang (Yangtze) River, China, Mar. Chem., 107, 342-356, 2007. 